\title{
Prospective Teachers' Personal Characteristics to Multicultural Education*
}

\author{
Menekse Eskici \\ Department of Educational Science, Faculty of Science and Art, Kirklareli University, Turkey
}

Copyright $(2016$ by authors, all rights reserved. Authors agree that this article remains permanently open access under the terms of the Creative Commons Attribution License 4.0 International License

\begin{abstract}
The aim of this paper is to determine prospective teachers' personal characteristics to multicultural education. It is also aimed to reveal whether there are meaningful differences in prospective teachers' personal characteristics to multicultural education according to their genders, age and number of siblings. The descriptive model was chosen to analyze in this paper. Likewise quantitative data was collected. The participants of the paper are 308 (220 female and 88 male) prospective teachers studying at Kirklareli University pedagogical formation certificate training program in the 2015-2016 academic year. The data collected by using the Turkish version of "Multicultural Personality Questionnaire". The data of this research were analyzed by SPSS 17 . During the analysis of data arithmetic mean, standard deviation, $\mathrm{t}$-test, the analysis of one way variance (ANOVA) and LSD test were used. According to these results prospective teachers' scores of "Multicultural Personality Questionnaire" has been found to be high. "Multicultural Personality Questionnaire" sub-dimensions were examined. Prospective teachers' multicultural personality has been highest in "cultural empathy" sub-dimensions and prospective teachers' multicultural personality has been lowest in "flexibility" sub-dimensions. Meaningful differences were found in favor of female prospective teachers toward "cultural empathy" and "emotional balance" sub-dimensions of the questionnaire. Meaningful differences was found in "Multicultural Personality Questionnaire" according to prospective teachers' ages but no meaningful differences was found in "Multicultural Personality Questionnaire" according to prospective teachers' number of siblings.
\end{abstract}

Keywords Prospective Teachers, Personal Characteristics, Multicultural Education

\section{Introduction}

Besides technological developments in the world, different point of views among countries causes let them get closer which means no boundaries between countries.It is much more easier to communicate with the furthest location thanks to internet and smart phones etc. The rate of communication among Different religions, different races, different cultures, different people speaking different languages has increased considerably. Therefore people accept differences, and they communicate easily. For instance a christian who was born and grow up in a chiristian country respect a muslim, who prays 5 times in a day and doesn't eat pig meat or a person who resprets an asian's interesting greeting style. No doubt, social developments have effected educational process. Especially higher education is suitable for multicultural education. Student exchange programs such as Erasmus and Da vinci supports multicultural education. Also migration and students' preferences to continue their education in abroad are the results of multicultural trend in education.

Multicultural education is a designing process among students from different cultures which aims to introduce and resprect ethnical, social, cultural, religional, sexual differences so that there could be equal educatioal conditions [1]; [6]. The start of multicultural educaion was in 1960s and 1970s. This period is known with social unrest and reforms and white population was dominant. Unequality has been a subject in minority groups. A lot of social/educational program was designed in that period [38]. Altough it has been discussed as a dicipline in 1960s, Eskici [24] has stated all societies has multicultural form so multicultural education started with the educaion from the beginning. At first multicultural education has focused on ethnical differences later it has dealt with problems of people who are accepted as "different" in a society (minorities, students who need special education, female children etc..) [45]. The main aims of multicultural education are to prepare students for the democratic world in the growing diversity, to make students active 
participants fort he teaching-learning process, to provide educational euqality [29]; [25]; [27]. Multicultural education focuses on differences in a society and tries to keep balance of the society. Mwonga [38] has stated that multicultural education tries to give priority to marginal groupsin order to improve active democratic citizenship. In addition to Mwonga [38], Pang [40] pointed out that multicultural education might be a starting point for solving unequality problems in a society. Multicultural education has some principles. Gorski [28] has stated these principles as :

1. Every student should have equal opportunity to make it happen their potentials.

2. Every student should prepare himself/herself for the multicutural society.

3. Every teacher has to be ready to teach effectively for every student from different cultures.

4. Schools has to be active participants to end the pressure in their walls and they should grow up socially and critically active and aware students.

5. Education should be student centered and it should involve students' opinions

6. Educators, activists and others should play an active role on revising education process and how it effects students' learning. (assessment methods, school physicology, consultancy applications, educational materials, and coursebooks...etc).

In addition to Gorski [28], Banks [5] have expressed 5 main points: 1.content İntegration 2. knowledge construction, 3. prejudice reduction, 4.equity pedagogy, 5 . empowering school culture.

When Banks [5] and Gorski [28]'s statements are examined it can be concluded that they focus on creating a student centered active learning athmosphere, providing equal learning conditions, effective consultancy, effective school managing. It can be said that Abdullah and Ghaffar [1] support these statements.

At first multicultural education was accepted as an initative in a dominant curriculum which emphasizes adding more concent and supporting cultural diversity [49], later a lot of specialists have added new approaches [13]. Teachers have great responsibility to apply multicultural education. And a key role to maintain equal education conditions. Therefore teachers' behaviour and their perception about multicultural education is impontant. In other words it is related with how teachers combine multiculturalism to education around common points [47]. The need of training teachers for different students groups has been a debate [46]. In order to be a multicultural educator, Gorski [28] states that a teacher has to renew himself/herself, [54] states that a teacher should have three main skills: "understanding other's culture", "understanding himself/herself", "academic multicultural skills". These are closely related with teachers'personal qualifications.

Personality is defined as "characteristics, psychological qualifications peculiar to someone [51] and "the mix of characteristics and its quality" [39]. No doubt, teachers should have defitine qualifications to teach in a multicultural way. Since personality is a complex term, it is clear that multicultural personality is not a one sided term [42]. Van der Zee \& Van Oudenhoven [53] have stated that a multicultural personality has five components: cultural empathy", "open-mindedness", "social initiative", "flexibility" and "emotional stability". It is clearly understood that teachers and teacher candicates should have multicultural personalities. It can be said that multicultural personality has significant role in this process.

\section{Objectives}

The aim of this paper is to determine prospective teachers' personality characteristics to multicultural education. It is also aimed to reveal whether there are meaningful differences in prospective teachers' personality characteristics to multicultural education according to their genders, age and number of siblings.

\section{Material and Methods}

Determining prospective teachers' personality characteristics to multicultural education was aimed in this paper. So that descriptive model was used in this paper. Also quantitative data was used.

\subsection{Participants}

The participants of the paper are 308 (220 female and 88 male) prospective teachers studying at Kurklareli University pedagogical formation certificate training program in the 2015-2016 academic year. The features of participants are presented in Table1.

It can be seen in Table 1 participants' age distribution by gender, number of sibling and percentages. It can be said based on table 1 the participants consists of 93 female between the ages 20-25, 64 female between the ages 26-30, 32 female between the ages $31-35,31$ female 36 years and over and 33 male between the ages 20-25, 36 male between the ages 26-30, 9 male between the ages 31-35, 10 male 36 years and over. As well as 21 participants haven't any sibling, 81 participants have only one sibling, 69 participants have two siblings, 51 participants have three siblings, 36 participants have four siblings and 50 participants have five and over siblings. 
Table 1. The features of participants

\begin{tabular}{|c|c|c|c|c|c|c|c|}
\hline \multirow{2}{*}{\multicolumn{3}{|c|}{ Number of sibling }} & \multirow{3}{*}{$\frac{20-25}{6}$} & \multicolumn{2}{|c|}{ age } & \multirow[b]{2}{*}{$36+$} & \multirow[b]{2}{*}{ Total } \\
\hline & & & & $26-30$ & $31-35$ & & \\
\hline \multirow[t]{2}{*}{0} & gender & female & & 5 & 2 & 1 & 14 \\
\hline & & male & 2 & 4 & 1 & 0 & 7 \\
\hline & & & 8 & 9 & 3 & 1 & 21 \\
\hline \multirow[t]{3}{*}{1} & gender & female & 29 & 20 & 8 & 6 & 63 \\
\hline & & male & 5 & 9 & 1 & 3 & 18 \\
\hline & & & 34 & 29 & 9 & 9 & 81 \\
\hline \multirow[t]{3}{*}{2} & gender & female & 19 & 15 & 8 & 3 & 45 \\
\hline & & male & 12 & 8 & 3 & 1 & 24 \\
\hline & & & 31 & 23 & 11 & 4 & 69 \\
\hline \multirow[t]{3}{*}{3} & gender & female & 18 & 12 & 7 & 5 & 42 \\
\hline & & male & 3 & 4 & 1 & 1 & 9 \\
\hline & & & 21 & 16 & 8 & 6 & 51 \\
\hline \multirow[t]{3}{*}{4} & gender & female & 9 & 6 & 2 & 10 & 27 \\
\hline & & male & 3 & 2 & 1 & 3 & 9 \\
\hline & & & 12 & 8 & 3 & 13 & 36 \\
\hline \multirow[t]{3}{*}{5 and over } & gender & female & 12 & 6 & 5 & 6 & 29 \\
\hline & & male & 8 & 9 & 2 & 2 & 21 \\
\hline & & & 20 & 15 & 7 & 8 & 50 \\
\hline
\end{tabular}

\subsection{Data Collection}

The data were collected by survey technique.

\subsection{Data Collection Tool}

The data collected using the "Multicultural Personality Questionnaire" that developed by Van Der Zee ve Van Oudenhoven [53] and adapted to Turkish by Polat [42]. "Multicultural Personality Questionnaire" consists of 33 items and five sub-dimensions "cultural empathy", "open-mindedness", "social initiative", "flexibility" and "emotional stability". Reliability alpha coefficient of "Multicultural Personality Questionnaire" .82, "cultural empathy" sub-dimensions .87, "social initiative" sub-dimensions .73, "emotional stability" sub-dimensions .65, "open-mindedness" sub-dimensions .66, "flexibility" sub-dimensions .67 were found. The highest score of "Multicultural Personality Questionnaire" is 165, the lowest score of "Multicultural Personality Questionnaire" is 33 .

\subsection{Analyzing Data}

The data of this research were analyzed by SPSS 17 .
Because of some groups' participants (prospective teachers who have no sibling) numbers are less than 30 in order to test whether the data parametric or nonparametric One Sample Kolmogorov Smirnov Test was applied. The results show that the data is parametric (asymp. $\mathrm{Sig}=.30, \mathrm{p}<.05$ ). During the analysis of data arithmetic mean, standard deviation, t-test, the analysis of one way variance (ANOVA) and LSD test were used.

\section{Findings}

This part of the research includes findings obtained from analysis results.

\subsection{Prospective Teachers' Personality Traits According to the Multicultural Education}

Mean and standard deviation values were calculated according to the prospective teachers' personality traits towards the multicultural education of which was determined by "Multicultural Personality Questionnaire" and results were presented in Table 2 . 
Table 2. The Arithmetic Mean and Standard Deviation Results According To Scale Dimensions

\begin{tabular}{|c|c|c|c|c|c|}
\hline Sub-dimension & $\begin{array}{l}\text { Number } \\
\text { of Items }\end{array}$ & $\mathbf{N}$ & $\bar{x}$ & SS & $\begin{array}{l}\text { Average size of the } \\
\text { Items of } \\
\text { dimension }(\bar{X} \\
\text { /Number of Items) }\end{array}$ \\
\hline $\begin{array}{l}\text { Cultural } \\
\text { Empathy }\end{array}$ & 11 & 308 & 46.24 & 6.26 & 4,20 \\
\hline $\begin{array}{c}\text { Social } \\
\text { Initiatives }\end{array}$ & 6 & 308 & 21.13 & 3.01 & 3.52 \\
\hline $\begin{array}{l}\text { Emotional } \\
\text { Balance }\end{array}$ & 7 & 308 & 22.17 & 3.97 & 3.17 \\
\hline Openness & 5 & 308 & 19.31 & 3.30 & 3.86 \\
\hline Flexibility & 4 & 308 & 10.97 & 3.09 & 2.74 \\
\hline $\begin{array}{c}\text { Multicultural } \\
\text { Personality }\end{array}$ & 33 & 308 & 118.63 & 12.19 & 3.59 \\
\hline
\end{tabular}

According to table 2 it was seen that the sub-dimensions of "Multicultural Personality Questionnaire" don't contain same number of item. For this reason the means of items were used for interpreting.

As it is seen on the table 2 means of "Multicultural Personality Questionnaire" sub-dimensions sorted from highest to lowest listed as follows; "cultural empathy" $((\overline{\mathrm{X}}$ /İtem number $=4.20)$. "open-mindedness" ( $\bar{X}$ /İtem number $=3.86)$. "social initiatives" $(\bar{X} /$ İtem number $=3.52)$. "emotional stability $(\bar{X} /$ İtem number $=3.17)$ "flexibility" $(\bar{X} /$ İtem number $=2.74)$. According to these results, "cultural empathy" sub-dimension is most participated sub-dimension of scale for prospective teachers. "flexibility" sub-dimension is the least participated sub-dimension of scale for prospective teachers.

\subsection{Prospective Teachers' Multicultural Personality Traits regarding To Their Gender}

Table 3. Prospective Teachers' Multicultural Personality Traits By Their Gender

\begin{tabular}{|c|c|c|c|c|c|c|c|}
\hline Dimensions & Gender & $\mathrm{N}$ & $\bar{X}$ & SS & $\mathrm{Sd}$ & $\mathrm{t}$ & $\mathrm{p}$ \\
\hline \multirow{2}{*}{ Cultural Empathy } & female & 220 & 46.78 & 5.99 & \multirow{2}{*}{306} & \multirow{2}{*}{2.42} & \multirow{2}{*}{.02} \\
\hline & male & 88 & 44.89 & 6.75 & & & \\
\hline \multirow{2}{*}{ Social Initiatives } & female & 220 & 21.01 & 2.96 & \multirow{2}{*}{306} & \multirow{2}{*}{-1.04} & \multirow{2}{*}{.30} \\
\hline & male & 88 & 21.41 & 3.14 & & & \\
\hline \multirow{2}{*}{ Emotional stability } & female & 220 & 22.50 & 3.79 & \multirow{2}{*}{306} & \multirow{2}{*}{2.36} & \multirow{2}{*}{.02} \\
\hline & male & 88 & 21.33 & 4.30 & & & \\
\hline \multirow{2}{*}{ "open-mindedness" } & female & 220 & 19.36 & 3.27 & \multirow{2}{*}{306} & \multirow{2}{*}{.42} & \multirow{2}{*}{.68} \\
\hline & male & 88 & 19.18 & 3.38 & & & \\
\hline \multirow{2}{*}{ Flexibility } & female & 220 & 10.90 & 3.15 & \multirow{2}{*}{306} & \multirow{2}{*}{-.71} & \multirow{2}{*}{.48} \\
\hline & male & 88 & 11.17 & 2.94 & & & \\
\hline \multirow{2}{*}{$\begin{array}{l}\text { Multicultural } \\
\text { Personality }\end{array}$} & female & 220 & 119.25 & 11.87 & \multirow{2}{*}{306} & \multirow{2}{*}{1.40} & \multirow{2}{*}{.16} \\
\hline & male & 88 & 117.10 & 12.90 & & & \\
\hline
\end{tabular}

$\mathrm{P}<.05$
Mean and standard deviation values were calculated and t-test was done to determine the difference whether it was changing by prospective teachers' gender according to the prospective teachers' multicultural personality traits. Results are shown on the Table 3.

According to table 3 there are meaningful difference between male and female prospective teachers in "cultural empathy" and "emotional stability" sub-dimensions of scale. This difference is in favor of female prospective teachers.

\subsection{Prospective Teachers' Multicultural Personality Traits According To Their Ages}

Mean and standard deviation values were calculated and One Way ANOVA was done to determine the difference whether it was changing by prospective teachers' ages according to the prospective Teachers' multicultural personality traits and results are shown on the table 4 .

According to table 4 "cultural empathy", "open-mindedness", "flexibility" sub-dimensions of "Multicultural Personality Questionnaire" and multicultural personality as being the overall scale are most participated by 36 and older aged prospective teachers; "emotional stability" dimension of scale is only most participated by 26-30 aged prospective teachers.

LSD test was used to determine the mean value differences whether it was meaningful to prospective teachers' ages according to sub dimensions. Results are shown on the table 3 . As it is seen on the table 3 there is a meaningful difference between 36 and older aged prospective teachers and 31-35 aged prospective teachers in overall the scale and social Initiatives dimension of "Multicultural Personality Questionnaire". mean of 36 and older aged prospective teachers' Multicultural Personality Traits and social Initiatives scores are higher than 31-35 aged prospective teachers' Multicultural Personality Traits and social Initiatives scores.in the same way there is a meaningful difference between 36 and older aged prospective teachers and 20-25 aged prospective teachers in overall the scale and Flexibility dimension of "Multicultural Personality Questionnaire". mean of 36 and older aged prospective teachers' multicultural personality traits and social initiatives sub-dimension scores are higher than mean of 20-25 aged prospective teachers' multicultural personality traits and "flexibility" sub-dimension scores. Also there is a meaningful difference between 36 and older aged prospective teachers and 26-30 aged prospective teachers in "open-mindedness" sub-dimension of "Multicultural Personality Questionnaire". mean of 36 and older aged prospective teachers' "open-mindedness" sub-dimension scores are higher than mean of 26-30 aged prospective teachers' "open-mindedness" sub-dimension scores. 
Table 4. ANOVA Results of "Multicultural Personality Questionnaire" Scores According to Prospective Teachers' Ages

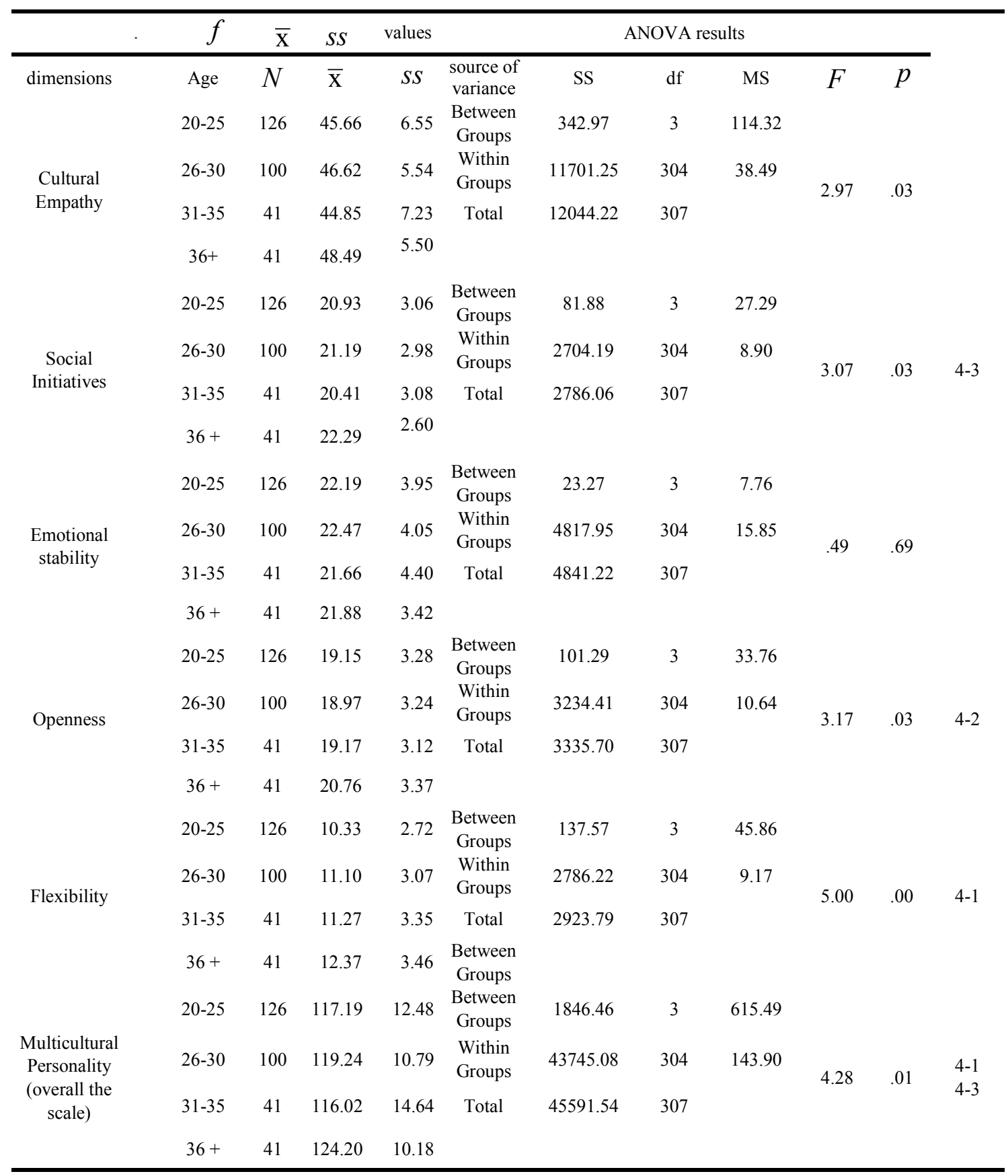

\subsection{Prospective Teachers' Multicultural Personality Traits According To Their Number Of Siblings}

Mean and standard deviation values were calculated and ANOVA was done to determine the difference whether it was changing by prospective teachers' number of siblings according to the prospective teachers' multicultural personality traits. Results are shown on the table 5. 
Table 5. ANOVA Results Of Multicultural Personality Scale Scores According To Prospective Teachers' Number Of siblings

\begin{tabular}{|c|c|c|c|c|c|c|c|c|c|c|}
\hline \multirow[b]{2}{*}{ dimensions } & \multicolumn{4}{|c|}{$f \cdot \overline{\mathrm{x}}$ ve $s s$ values } & \multicolumn{6}{|c|}{ ANOVA results } \\
\hline & $\begin{array}{l}\text { Number of } \\
\text { brother/sister }\end{array}$ & $N$ & $\bar{X}$ & $S S$ & $\begin{array}{l}\text { source of } \\
\text { variance }\end{array}$ & SS & df & MS & $F$ & $p$ \\
\hline \multirow{4}{*}{$\begin{array}{l}\text { Cultural } \\
\text { Empathy }\end{array}$} & 0 & 21 & 45.14 & 6.65 & $\begin{array}{c}\text { Between } \\
\text { Groups }\end{array}$ & 213.40 & 5 & 42.68 & & \\
\hline & 1 & 81 & 45.93 & 5.82 & $\begin{array}{l}\text { Within } \\
\text { Groups }\end{array}$ & 11830.83 & 302 & 39.17 & & \\
\hline & 2 & 69 & 46.06 & 5.49 & Total & 12044.22 & 307 & & 1.09 & .37 \\
\hline & 3 & 51 & 47.90 & 5.88 & & & & & & \\
\hline \multirow{8}{*}{$\begin{array}{c}\text { Social } \\
\text { Initiatives }\end{array}$} & 4 & 36 & 46.67 & 6.14 & & & & & & \\
\hline & $5+$ & 50 & 45.46 & 8.00 & & & & & & \\
\hline & 0 & 21 & 21.57 & 3.09 & $\begin{array}{c}\text { Between } \\
\text { Groups }\end{array}$ & 16.96 & 5 & 3.39 & & \\
\hline & 1 & 81 & 21.15 & 2.86 & $\begin{array}{l}\text { Within } \\
\text { Groups }\end{array}$ & 2769.10 & 302 & 9.17 & & \\
\hline & 2 & 69 & 20.87 & 3.18 & Total & 2786.06 & 307 & & .37 & .87 \\
\hline & 3 & 51 & 21.33 & 2.76 & & & & & & \\
\hline & 4 & 36 & 21.39 & 2.83 & & & & & & \\
\hline & 5 and upper & 50 & 20.86 & 3.42 & & & & & & \\
\hline \multirow{4}{*}{$\begin{array}{l}\text { Emotional } \\
\text { stability }\end{array}$} & No brother/sister & 21 & 20.19 & 3.37 & $\begin{array}{c}\text { Between } \\
\text { Groups }\end{array}$ & 129.84 & 5 & 25.97 & & \\
\hline & 1 & 81 & 22.07 & 3.84 & $\begin{array}{l}\text { Within } \\
\text { Groups }\end{array}$ & 4711.38 & 302 & 15.60 & & \\
\hline & 2 & 69 & 22.06 & 4.13 & Total & 4841.22 & 307 & & 1.67 & .14 \\
\hline & 3 & 51 & 22.14 & 3.85 & & & & & & \\
\hline \multirow{8}{*}{$\begin{array}{l}\text { Open-mindedn } \\
\text { ess }\end{array}$} & 4 & 36 & 23.17 & 3.90 & & & & & & \\
\hline & $5+$ & 50 & 22.62 & 4.22 & & & & & & \\
\hline & 0 & 21 & 19.10 & 3.03 & $\begin{array}{c}\text { Between } \\
\text { Groups }\end{array}$ & 48.62 & 5 & 9.72 & & \\
\hline & 1 & 81 & 19.30 & 3.15 & $\begin{array}{l}\text { Within } \\
\text { Groups }\end{array}$ & 3287.08 & 302 & 10.88 & & \\
\hline & 2 & 69 & 18.93 & 3.29 & Total & 3335.70 & 307 & & .89 & .49 \\
\hline & 3 & 51 & 19.90 & 3.40 & & & & & & \\
\hline & 4 & 36 & 19.89 & 3.63 & & & & & & \\
\hline & $5+$ & 50 & 18.92 & 3.31 & & & & & & \\
\hline \multirow{4}{*}{ Flexibility } & 0 & 21 & 11.38 & 3.72 & $\begin{array}{c}\text { Between } \\
\text { Groups }\end{array}$ & 14.11 & 5 & 2.82 & & \\
\hline & 1 & 81 & 10.83 & 2.95 & $\begin{array}{l}\text { Within } \\
\text { Groups }\end{array}$ & 2909.69 & 302 & 9.64 & & \\
\hline & 2 & 69 & 10.72 & 2.66 & Total & 2923.79 & 307 & & .29 & .92 \\
\hline & 3 & 51 & 11.12 & 3.51 & & & & & & \\
\hline \multirow{8}{*}{$\begin{array}{l}\text { Multicultural } \\
\text { Personality } \\
\text { (overall the } \\
\text { scale) }\end{array}$} & 4 & 36 & 10.97 & 3.05 & & & & & & \\
\hline & $5+$ & 50 & 11.24 & 3.24 & & & & & & \\
\hline & 0 & 21 & 116.05 & 13.57 & $\begin{array}{c}\text { Between } \\
\text { Groups }\end{array}$ & 680.11 & 5 & 136.02 & & \\
\hline & 1 & 81 & 118.11 & 10.68 & $\begin{array}{l}\text { Within } \\
\text { Groups }\end{array}$ & 44911.44 & 302 & 148.71 & & \\
\hline & 2 & 69 & 117.57 & 10.89 & Total & 45591.54 & 307 & & .92 & .47 \\
\hline & 3 & 51 & 120.76 & 11.20 & & & & & & \\
\hline & 4 & 36 & 120.97 & 11.65 & & & & & & \\
\hline & $5+$ & 50 & 118.18 & 16.30 & & & & & & \\
\hline
\end{tabular}


According to Table 5 "cultural empathy" and "open-mindedness" sub- dimensions of "Multicultural Personality Questionnaire" are the most participated by prospective teachers who have 3 siblings; "emotional stability" sub-dimension of "Multicultural Personality Questionnaire" is the most participated by prospective teachers who have 5 and over siblings; "flexibility" sub-dimension of "Multicultural Personality Questionnaire is the most participated by prospective teachers who have no siblings; multicultural personality as being the overall of "Multicultural Personality Questionnaire" and "social nitiatives" sub-dimension of "Multicultural Personality Questionnaire" are the most participated by prospective teachers who had 4 siblings. According to ANOVA results no meaningful difference was found.

\section{Discussion}

The aim of this paper is to determine prospective teachers' personal characteristics to multicultural education. It is also aimed to reveal whether there are meaningful differences in prospective teachers' personal characteristics to multicultural education according to their genders, age and number of siblings. The data collected by using the "Multicultural Personality Questionnaire" that developed by Van Der Zee and Van Oudenhoven [53] and adapted to Turkish by Polat [42].

Prospective teachers' scores of "Multicultural Personality Questionnaire" and the Questionnaire sub-dimensions were examined. By considering the questionnaire ranges as 1.00-1.79 "very low", 1.80-2.59 "low", 2.60-3.39 "middle", 3.40-4.19 "high", 4.20-5.00 "quite high" arithmetic means of the questionnaire sub-dimensions can be interpreted as; "cultural empathy" sub-dimensions $(\bar{X}=4.20)$ is quite high, "open-mindedness" sub-dimensions $(\bar{X}=3.86)$ is high, "social initiatives" sub-dimension $(\bar{X}=3.52), \quad$ is high, "emotional stability" sub-dimension $(\bar{X}=3.17)$ is middle, "flexibility" sub-dimension $(\bar{X}=2.74)$ is middle. In this context it is seen that the prospective teachers the most participated dimensions are respectively "cultural empathy", "open-mindedness", "social initiatives", "emotional stability" and "flexibility". Besides prospective teachers' total scores which revealed from "Multicultural Personality Questionnaire" $(\bar{X}=3.59)$ has been found to be high. The study carried out by Polat [42]'s result support this paper result. According to the study carried out by Polat [42]'s result show that prospective teachers' scores of "Multicultural Personality Questionnaire" is also high, moreover "cultural empathy" sub-dimension has the highest score, "open-mindedness" sub-dimension has the second highest score, "social initiatives" sub-dimension has the third highest score and "emotional stability" sub-dimension has middle level alike this paper result.

Results of the study carried out by Polat and Metin [44] as well as the study carried out by Polat and Barka [43] parallel with the study carried out by Polat [42] and this paper result about teachers' scores of "Multicultural Personality Questionnaire" is high, moreover "cultural empathy" sub-dimension has the highest score, "open-mindedness" sub-dimension has the second highest score, "social initiatives" sub-dimension has the third highest score.

Additionally when examining the literature it is seen that faculty members [3]; [24];[35], teachers [31]; [50] and prospective teachers [9]; [12]; [23] have positive attitude towards multicultural education. İt can be said that attitude and personal characteristics related to each other, because personal characteristics influence to attitudes. It can be interpreted as a result, educators have well attitude and improvable personal characteristics. Otherwise there are some research pointed out that teachers and prospective teachers should be trained on multiculturalism in the education [7]; [22]; [26]; [28]; [36]; [37]; [42]; [48]. t-test was used to determine whether personal characteristics to multicultural education changes according to the gender of the prospective teachers. As a result of analysis meaningful differences was found in favor of female prospective teachers toward "cultural empathy" and "emotional stability" sub-dimensions of the questionnaire. There are some research supported this finding in the literature. Similarly the study carried out by Bulut and Sarıçam[11] meaningful differences was found in favor of female prospective teachers toward "cultural empathy" sub-dimensions of the questionnaire. Also Bulut and Sarıçam [11] found out meaningful differences in favor of female teachers toward "cultural empathy", "flexibility", "open-mindedness" and "emotional stability" sub-dimensions of the questionnaire. According to the study carried out by Çoban, Karaman and Doğan [17] women more tolerant than men in the "political view" sub-dimension. Plus according to the study carried out by Demir [19] female faculty members more care multiculturalism than male faculty members in the "egalitarian pedagogy" dimension. In addition results of the study carried out by Demircioğlu and Özdemir [20] show that female prospective teachers have more positive attitudes towards multiculturalism in education that male prospective teachers. The study carried out by Chepyator-Thomson, You, \& Russell [15], study carried out by Koçak and Özdemir [33] and the studies carried out by Alanay and Aydın [2] and carried out by Pettus and Allain [41] support that female educators' opinions on multiculturalism in education are more much positive than male educators' opinions. It was deduced that generally female educators think about multiculturalism more positively than male educators. For the rest there are some research result in the literature that no meaningful differences according to educators' gender and their opinion on multicultural education [18]; [30]; [52];[56].

ANOVA was used to determine whether personal characteristics to multicultural education changes according to the age of the prospective teachers. As a result of analysis meaningful differences was found toward "social Initiatives", "open-mindedness", "flexibility" 
sub-dimensions of the questionnaire and totally of "Multicultural Personality Questionnaire". LSD test was used to determine the source of the difference. According to LSD test there are meaningful differences in favor of 36 years and older prospective teachers toward "social initiatives", "open-mindedness", "flexibility" sub-dimensions of the questionnaire and totally of "Multicultural Personality Questionnaire". According to the study carried out by Bulut, and Sarıçam [11] inservice teachers' scores about personal characteristics to multicultural education and attitude towards multicultural education higher than preservice teachers' scores about personal characteristics to multicultural education and attitude towards multicultural education. Considering inservice teachers older than preservice teachers it is possible to infer from the result of the study carried out by Bulut and Sarıçam [11] and this paper finding age is determinant on multicultural education opinion. Additionally the study carried out by Pettus and Allain [41] 26 ages and older prospective teachers have more positive attitude than younger prospective teachers. It can be said that educators became older they have more multicultural personality. On the other hand the study carried out by Hammer, Bennett and Wisemann (2003)[30] reveals no significant effects by age.

ANOVA was used to determine whether personal characteristics to multicultural education changes according to the number of sibling of the prospective teachers. As a result of analysis no meaningful differences was found. There are some research findings in the literature can be said support this paper finding. There are no meaningful differences between number of sibling and communication skills [10], inclination to multicultural education [42], critical thinking skills [14], empathic skills [21]; [34], life satisfaction [16]. As well as there are some research findings in the literature indicate that individual who have one, two or three not more much siblings have more self-esteem [8]; [32], social skills [4] and empathic skills [55] than the others. These research findings said to be overlapping with this paper finding because in this paper found out that prospective teachers who have two or three sibligs have higher inclination to multicultural education than the others.

\section{Conclusions}

Teacher as a practitioner of educational curriculum is a person. Therefore teachers have personal characteristics. It is inevitable that teachers' personal characteristics affect educational process. One of the personal characteristics is multicultural personality. Recently multiculturalism became so widespread concept everywhere where people live. Training environments also multicultural environments. Because a lot of people who come from different cultures interact with each other. Teachers always became a guide to direct to students behaviours. Hence it is possible to say that teachers' multicultural personality is an issue that needs to be emphasized.

At the end of this paper it can be said that prospective teachers the most participated dimensions are respectively "cultural empathy", "open-mindedness", "social initiatives", "emotional stability" and "flexibility". Besides prospective teachers' total scores which revealed from "Multicultural Personality Questionaire" has been found to be high.

Female prospective teachers have more "cultural empathy" and "emotional stability" personality than male prospective teachers. 36 years and older prospective teachers have more "social initiatives", "open-mindedness", "flexibility" personality than the younger prospective teachers.

\section{Recommendations}

In the light of the this research findings prospective teachers should be trained about multiculturalism. Prospective teachers should be direct to exchange programs between universities in different countries. Teacher training programmes sould be revised considering multiculturalism. As well as views of prospective teachers studying at different universities about multiculturalism should be investigated considering other variables such as religion and region. It can be investigated the reasons of the findings of this paper.

\section{Note}

*The abstract of this paper was presented at 2nd International Conference on Lifelong Learning and Leadership for All (ICLEL-16), in Liepaja on July, 21-23, 2016.

\section{REFERENCES}

[1] Abdullah, S. N. S. \& Ghaffar, M. N. A. (2010). Multicultural education in Malaysian perspective: Instruction and assessment. University Technology of Malaysia.

[2] Alanay, H. \& Aydın, H. (2016). Eğitim Fakültesi Lisans Öğrencilerinin Çokkültürlü Eğitime Dair Tutumları. Eğitim ve Bilim, 41(184). 169-191.

[3] Assaf, L. C., Garza, R., \& Battle, J. (2010). Multicultural teacher education: Examining the perceptions, practices, and coherence in one teacher preparation program. Teacher Education Quarterly, 37(2), 115-135.

[4] Avşar, Z. \& Kuter, F. Ö. (2007). Beden eğitimi ve spor bölümü öğrencilerinin sosyal beceri düzeylerinin belirlenmesi (Uludağ Üniversitesi örneği). Eğitimde Kuram ve Uygulama, 3(2), 197-206.

[5] Banks, J. A. (2004). Multicultural education: Historical development, dimensions, and practice. In J. A. Banks \& C. A. M. Banks (Eds.), Handbook of research on multicultural education (2.bask1., s. 3-29). San Francisco: Jossey-Bass. 
[6] Banks, J. A. (2009). Multicultural education: Dimensions and paradigms. In J. A. Banks (Ed.), The Routledge international companion to multicultural education (s. 9-32). New York, NY: Routiedge.

[7] Başarır, F., Sarı, M. \& Çetin, A. (2014). Examination of teachers' perceptions of multicultural education. Pegem Journal of Education \& Instruction, 4(2), 91-110.

[8] Baybek, H. \& Yavuz, S. (2005). Muğla üniversitesi öğrencilerinin benlik saygılarının incelenmesi. Sosyal ve Beşeri Bilimler Araştırmaları Dergisi, 1(14). 73-95.

[9] Bell, C. A., Horn, B. R., \& Roxas, K. C. (2007). We know it's service, but what are they learning? Preservice teachers' understandings of diversity. Equity \& Excellence in Education, 40(2), 123-133.

[10] Bingöl, G. \& Demir, A. (2011). Amasya sağlık yüksekokulu ögrencilerinin iletişim becerileri. Göztepe Tip Dergisi, 26(4), 152-159.

[11]Bulut, M., \& Sariçam, H. (2016). Okul öncesi öğretmen ve öğretmen adaylarinda çokkültürlü kişiliğin çokkültürlü eğitim tutumlari üzerindeki etkisinin incelenmesi. Kırıkkale Üniversitesi Sosyal Bilimler Dergisi, 6(1).295-322.

[12] Capella-Santana, N. (2003). Voices of teacher candidates: Positive changes in multicultural attitudes and knowledge. The Journal of Educational Research, 96(3), 182-190.

[13] Castagno, A. E. (2013). Multicultural education and the protection of Whiteness. American Journal of Education, 120(1), 101-128.

[14] Çekin, A. (2013). Din kültürü ve ahlak bilgisi öğretmen adaylarinin eleştirel düşünme becerilerinin bazi değişkenler açisindan incelenmesi. Review of the Faculty of Divinity of Amasya University, (1).25-46.

[15] Chepyator-Thomson, J. R., You, J., \& Russell, J. (2000). In-service physical education teachers: Background and understanding of multicultural education. Journal of In-service Education, 26(3), 557-568.

[16] Çivitci, A. (2009). İlköğretim öğrencilerinde yaşam doyumu: Bazı kişisel ve ailesel özelliklerin rolü. Uludağ Üniversitesi Eğitim Fakültesi Dergisi, 22(1).29-52.

[17] Çoban, A. E., Karaman, N. G. \& Doğan, T. (2010). Öğretmen adaylarının kültürel farklılıklara yönelik bakış açılarının çeşitli demografik değişkenlere göre incelenmesi. Abant İzzet Baysal Üniversitesi Eğitim Fakültesi Dergisi. 125-131.

[18] Coşkun, M. K. (2012). Din Kültürü ve Ahlak Bilgisi Öğretmen Adaylarının Çok Kültürlü Eğitime Yönelik Tutumları (İlahiyat-Eğitim DKAB Karşıllaştırmas1). Dumlupınar Üniversitesi Sosyal Bilimler Dergisi, 34, 33-44.

[19] Demir, S. (2012). Çok kültürlü eğitimin erciyes üniversitesi öğretim elemanlari için önem derecesi. Electronic Turkish Studies, 7(4). 1453-1475.

[20] Demircioğlu, E., \& Özdemir, M. (2014). Pedagojik formasyon öğrencilerinin çok kültürlü eğitime yönelik tutumlarının bazı değişkenlere göre incelenmesi. Ege Eğitim Dergisi, 15(1), 211-232.

[21] Derman, M. T. (2013). Çocukların empati beceri düzeylerinin ailesel etmenlere göre belirlenmesi. International Journal of Social Science 6 (1), 1365-1382.
[22] Dragowski, E. A., McCabe, P. C. \& Rubinson, F. (2016). Educators' reports on incidence of harassment and advocacy toward lgbtq students. Psychology in the Schools, 53(2), 127-142.

[23] Duarte, V. \& Reed, T. (2004). Learning to teach in urban settings. Childhood Education, 80(5), 245-250.

[24] Eskici, M. (2016). Faculty members' opinions about multiculturalism in higher education. Anthropologist, 24(1), $252-261$.

[25] Gaff, J. G. (1992). Beyond politics: The educational issues inherent in multicultural education. Change, 24 (1), 30-35.

[26] Garmon, M. A. (2004). Changing Preservice Teachers' Attitudes/Beliefs About Diversity What are the Critical Factors?. Journal of Teacher Education, 55(3), 201-213.

[27] Gay, G. (2000). Culturally Responsive Teaching: Theory, Research and Practice. New York: Teacher College Press.

[28] Gorski, P. C. (2009). What we're teaching teachers: An analysis of multicultural teacher education coursework syllabi. Teaching and Teacher Education, 25(2), 309-318.

[29] Halvorsen, A.L. \& Wilson, S.M. 2010. Social studies teacher education. In: P Peterson, E Baker, B McGaw (Eds.): International Encyclopedia of Education. $3^{\text {rd }}$ Edition. Oxford, UK: Elsevier Academic Press,

[30] Hammer, M. R., Bennett, M. J. \& Wiseman, R. (2003). Measuring intercultural sensitivity: The intercultural development inventory. International journal of Intercultural Relations, 27(4), 421-443.

[31] Horenczyk, G., \& Tatar, M. (2002). Teachers' attitudes toward multiculturalism and their perceptions of the school organizational culture. Teaching and Teacher Education, 18(4), 435-445.

[32] Karadağ, G., Güner, İ., Çuhadar, D. \& Uçan, Ö. (2008). Gaziantep Üniversitesi Sağlık Yüksekokulu hemşirelik öğrencilerinin benlik saygıları. Fırat Sağlık Hizmetleri Dergisi, 3(7), 29-42.

[33] Koçak, S., \& Özdemir, M. (2015). Öğretmen Adaylarının Çok Kültürlü Eğitime Yönelik Tutumlarında Kültürel Zekânın Rolü. İlköğretim Online, 14(4).1352-1369.

[34] Küçükkaragöz, H. Akay, Y., \& Canbulat, T. (2011). Bir Grup İlköğretim Öğrencisinin Bazı Psiko-Sosyal Değişkenlere Göre Empatik Beceri Düzeyleri. Uşak Üniversitesi Sosyal Bilimler Dergisi, 4(2), 88-100.

[35] Larke, P. \& Larke, A. (2009). Teaching diversity/multicultural education courses in the academy: Sharing the voices of six professors. Research in Higher Education Journal, 3(1),1-8.

[36] McAllister, G. \& Irvine, J. J. (2000). Cross cultural competency and multicultural teacher education. Review of Educational Research, 70(1), 3-24.

[37] Merilyn, B. C., Correia, M. G. \& Bleicher, R. E. (2010). Increasing preservice teachers' intercultural awareness through service-learning. International Journal of Research on Service-Learning in Teacher Education, 1(1), 1-19.

[38] Mwonga, C. (2005). Multicultural education: New path toward democracy. Upper Saddle River, NJ: Merrill. 
[39] Oxford dictionaries. (2016). Erişim Tarihi: 17 May 2016. http://www.oxforddictionaries.com/

[40] Pang, V. O. (2001). Multicultural education: A caring-centered, reflective approach. New York: McGraw- Hill Press.

[41] Pettus, A. M., \& Allain, V. A. (1999). Using a questionnaire to assess prospective teachers' attitudes toward multicultural education issues. Education, 119(4), 651-657.

[42] Polat, S. (2009). Öğretmen adaylarının çokkültürlü eğitime yönelik kişilik özellikleri, International Online Journal of Educational Sciences. 1 (1), 154- 164.

[43] Polat, S., \& Barka, T. O. (2014). Preservice teachers' intercultural competence: a comparative study of teachers in Switzerland and Turkey. Eurasian Journal of Educational Research, 54, 19-38.

[44] Polat, S. \& Metin, M. A. (2012). The Relationship Between the Teachers' Intercultural Competence Levels and the Strategy of Solving Conflicts. Procedia-Social and Behavioral Sciences, 46, 1961-1968.

[45] Ramsey, P. G. (2008). History and trends of multicultural education. NHSA Dialog, 11 (4), 206-214.

[46] Seidl, B. L., Monobe, G., Conley, M. D., Burgos, L. P., Rivera, H. J. \& Uchida, C. H. (2015). Multicultural apprenticeships in teacher education. Teaching Education, 26(3), 294-309.

[47] Sharma, S. (2011). Multicultural education: Teachers' perceptions and preparation. Journal of College Teaching \& Learning, 2(5), 53-64.

[48] Sleeter, C. E. (2001). Preparing teachers for culturally diverse schools research and the overwhelming presence of whiteness. Journal of Teacher Education, 52(2), 94-106.
[49] Sleeter, C. E., \& Grant, C. A. (1988). Making choices for multicultural art education: Five approaches to race, class, and gender. Columbus, $\mathrm{OH}$ : Merill.

[50] Söylemez, M. \& Kaya, Y. (2014). Determining teachers perception's about multiculturalizm and multicultural education: (diyarnakır's example). Dicle Üniversitesi Sosyal Bilimler Enstitüsü Dergisi, 6(11), 128-148.

[51] TDK. (2016). Türk Dil Kurumu Güncel Türkçe Sözlük. Erişim Tarihi: 01 Mayıs2016 .http://www.tdk.gov.tr/index.php?optio $\mathrm{n}=\mathrm{com} \_$gts\&arama $=$gts\&guid $=$TDK.GTS.57fd $7310 \mathrm{~cd} 1269579961$

[52] Tortop, H. S. (2014). Attitudes of candidate teachers towards multicultural and gifted education. Journal of Gifted Education Research, 2(2), $16-26$.

[53] Van Oudenhoven, J. P., \& Van der Zee, K. I. (2002). Predicting multicultural effectiveness of international students: The Multicultural Personality Questionnaire. International Journal of Intercultural Relations, 26(6), 679-694.

[54] Washington, E. D. (2003). The multicultural competence of teachers and challenge of academic achievement. In D. B. PopeDavis, H. L. K. Coleman, W. M. Liu\& R. L. Toporek (Edit)., Handbook of multicultural competencies in counseling and psychology. California: Sage Publications.

[55] Yiğitbaş, Ç., Deveci, S. E., Açık, Y., Ozan, A. T., \& Oğuzöncül, A. F. (2013). The empathic tendency and empathic skills of a group of students receiving health education. SDÜ Sağlık Bilimleri Dergisi, 4(1), 7-13.

[56] Yilmaz, F. \& Göçen, S. (2013). Sınıf öğretmeni adaylarinin kültürlerarasi duyarlilik hakkindaki görüşlerinin farkli değişkenlere göre incelenmesi. Adıyaman Üniversitesi Sosyal Bilimler Enstitüsü Dergisi, 6(15).373-392. 